\title{
RESOURCE BASED LEARNING DALAM PEMBELAJARAN BAHASA ARAB
}

\author{
Khaerun Nisa Nuur \\ Universitas Islam Negeri Alauddin Makassar \\ hjnisa82@mail.com
}

\begin{abstract}
This article examines a language approach used in teaching Arabic. Studying with Resource Based Learning focusses on students' point of view, not on the teachers. The students are asked to learn independently, so they experience a change from passive-receptive into active-partisipative strategy. This active-partisipative strategy allows the students in having freedom in learning process. It includes how students prepare their materials by utilizing many kinds of sources. Studying Arabic with Resource Based Learning approach could be applied to improve language skill (maharat al-lughah ), such as listening (maharah al-istima ), speaking (maharah al -kalam ), writing (maharah al-kitabah), and reading (maharah alqira'ah).

Keywords: Teaching Arabic, Approach , Resource Based Learning,
\end{abstract}

\begin{abstract}
Abstrak
Artikel ini membahas pendekatan bahasa yang digunakan dalam pembelajaran bahasa Arab. Belajar dengan resource based learning menekankan atau memusatkan kegiatan belajar pada peserta didik, bukan pada pendidik. Peserta didik diminta untuk belajar secara mandiri, sehingga mereka mengalami perubahan dari strategi belajar pasif-reseptif diharuskan menjadi strategi belajar aktif-partisipatif. Strategi aktifpartisipatif ini memungkinkan peserta didik memiliki kebebasan dalam proses belajar. Dalam hal ini peserta didik dituntut untuk dapat mempelajari sendiri bahan atau materi pembelajaran dengan memanfaatkan berbagai jenis sumber. Mempelajari bahasa Arab dengan pendekatan resource based learning dapat diterapkan untuk meningkatkan keterampilan berbahasa (maharat al-lughah), seperti menyimak (maharah alistima), berbicara (maharah al-kalam), menulis (maharah alkitabah), dan membaca ( maharah al-qira'ah).

Kata Kunci: Pembelajaran, Bahasa Arab, Pendekatan, Resource Based Learning
\end{abstract}




\section{A. Pendahuluan}

Sering dikatakan bahwa mengajar adalah mengorganisasikan aktivitas peserta didik dalam arti yang luas. Peranan tenaga pendidik bukan semata-mata memberikan informasi, melainkan juga mengarahkan dan memberi fasilitas belajar agar proses belajar lebih memadai. Pembelajaran mengandung arti setiap kegiatan yang dirancang untuk membantu seseorang mempelajari suatu kemampuan dan atau nilai yang baru. Proses pembelajaran pada awalnya meminta tenaga pendidik untuk mengetahui kemampuan dasar yang dimiliki oleh peserta didik meliputi kemampuan dasarnya, motivasinya, latar belakang akademisnya, latar belakang sosial ekonominya, dan lain sebagainya. Kesiapan tenaga pendidik untuk mengenal karakteristik peserta didik dalam pembelajaran merupakan modal utama penyampaian bahan belajar dan menjadi indikator suksesnya pelaksanaan pembelajaran.

Proses pembelajaran aktivitasnya dalam bentuk interaksi belajar mengajar dalam suasana interaksi edukatif, yaitu interaksi yang sadar akan tujuan, artinya interaksi yang telah dicanangkan untuk pencapaian tujuan pembelajaran yang telah dirumuskan pada satuan pelajaran. Materi pembelajaran dalam proses pembelajaran hanya merupakan perangsang tindakan pendidik yang memberikan dorongan dalam belajar yang tertuju pada pencapaian tujuan belajar. Dalam pembelajaran pendidik harus memahami hakekat materi pelajaran yang diajarkannya sebagai suatu pelajaran yang dapat mengembangkan kemampuan berfikir peserta didik dan memahami berbagai model pembelajaran yang dapat merangsang kemampuan peserta didik untuk belajar dengan perencanaan pengajaran yang matang oleh pendidik.

Pembelajaran dapat diartikan sebagai suatu proses interaksi antara peserta belajar dengan pengajar / instruktur dan / atau sumber belajar pada suatu lingkungan belajar untuk pencapaian tujuan belajar tertentu ${ }^{1}$ Proses pembelajaran tidak selalu efektif dan efisien dan hasil belajar mengajar tidak selalu optimal, karena ada sejumlah hambatan. Olehnya itu tenaga pendidik dituntut untuk memberikan materi pelajaran yang hanya berguna dan bermanfaat bagi peserta didik. Materi tersebut disesuaikan dengan kebutuhan mereka akan pelajaran tersebut. Belajar seperti ini akan lebih mengutamakan penguasaan ilmu dan diyakini akan memberikan peluang untuk peserta didik lebih kreatif dan tenaga pendidik lebih profesional. Dengan demikian pembelajaran akan lebih bermakna di mana tenaga pendidik mampu menciptakan kondisi belajar yang dapat membangun kreatifitas peserta didik untuk menguasai ilmu pengetahuan.

Pada dasarnya menumbuhkan minat belajar peserta didik sebetulnya tidaklah terlalu sulit. Dengan mengenali apa yang mereka sukai, maka minat belajarnya pun akan meningkat, dengan kata lain tenaga pendidik mengetahui apa yang dapat membuat peserta didik tertarik dan ingin belajar. Dalam hal pembelajaran bahasa Arab misalnya, pola pikir peserta didik yang menganggap bahwa bahasa Arab adalah salah satu bahasa yang susah dipelajari daripada bahasa lainnya dan minat baca terhadap buku-buku teks arab pun rendah, hal ini bisa saja disebabkan oleh metode pembelajaran bahasa Arab yang kurang menarik.

${ }^{1}$ Hamzah B. Uno, Model pembelajaran; Menciptakan Proses Belajar Mengajar yang Kreatif dan Efektif ( Cet.XI; Jakarta; Bumi Aksara, 2015 ), h. 54. 
Tujuan utama pembelajaran bahasa asing adalah pengembangan kemampuan peserta didik dalam menggunakan bahasa tersebut secara lisan maupun tulisan. Kemampuan menggunakan bahasa dalam dunia pengajaran bahasa disebut keterampilan berbahasa ( maharat al-lughah). Keterampilan tersebut ada empat , yaitu keterampilan menyimak ( maharah al-istima / listening skill), berbicara (maharah al -kalam / speaking skill), membaca (maharah al-qiraah / reading skill ) dan menulis (maharah al-kitabah / writing skill). Keempat keterampilan ini memiliki hubungan hierarkis yang tidak bisa dipisahkan satu sama lainnya. ${ }^{2}$ Keterampilan menyimak daan membaca dikategorikan ke dalam keterampilan reseptif ( al-maharat al-istiqbaliyyah/ receptive skills), sedangkan keterampilan berbicara dan menulis dikategorikan ke dalam keterampilan produktif ( al-maharat al-intajiyyah / productive skills).

Saat ini proses belajar mengajar berbasis aneka sumber belajar (resource based learning) menjadi tuntutan zaman. Pendekatan Resource Based Learning dapat diterapkan pada pembelajaran bahasa Arab untuk menghantarkan peserta didik menguasai berbagai macam keterampilan berbahasa dan memperoleh pengetahuan kebahasaan sesuai dengan kemampuan, minat dan kebutuhan peserta didik.

\section{B. Pembahasan}

\section{Pengertian Pendekatan Resource Based Learning}

"Resource" berasal dari bahasa Inggris yang artinya sumber, "based" berarti dasar dan "learning" berasal dari kata learn yang berarti belajar. Adapun yang dimaksud dengan Resource Based Learning yaitu segala bentuk dan model belajar yang langsung menghadapkan murid dengan suatu sumber belajar seperti buku, kitab, atau audio visual untuk mendapatkan pengetahuan, informasi at au penelitian.

Resource Based Learning ialah segala bentuk belajar yang langsung menghadapkan murid dengan suatu atau sejumlah sumber belajar secara individual atau kelompok dengan segala kegiatan belajar yang bertalian dengan itu, jadi bukan dengan cara yang konvensional di mana guru menyampaikan bahan pelajaran kepada murid, tetapi setiap komponen yang dapat memberikan informasi seperti perpustakaan, laboratorium, kebun, dan semacamnya juga merupakan sumber belajar.

Berdasarkan pengertian dan istilah di atas, maka yang dimaksud dengan pendekatan Resource Based Learning adalah merupakan berbagai alat dan sarana yang dapat digunakan oleh tenaga pendidik dalam proses pembelajaran sebagai perantara komunikasi dalam menyampaikan isi materi pelajaran.

${ }^{2}$ Zulhannan, Teknik Pembelajaran Bahasa Arab Interaktif( Cet. II; Jakarta; PT RajaGrafindo Persada, 2015 ), h. 76.

${ }^{3}$ S.Nasution, Berbagai Pendekatan dalam Proses Belajar dan Mengajar ( Cet XVI; Jakarta: Bumi Aksara, 2013 ), h.18.

${ }^{4}$ Syaiful Sagala, Konsep dan Makna Pembelajaran ( Cet. VI; Bandung: Alfabeta, 2008 ), h. 65. 


\section{Ciri-ciri Model Pembelajaran Resource Based Learning}

a. Resource Based Learning memanfaatkan sepenuhnya sumber informasi sebagai sumber belajar termasuk media audiovisual dan memberi kesempatan untuk merencanakan kegiatan belajar.

b. Resource Based Learning memberi kesempatan kepada peserta didik untuk belajar menurut kecepatan dan kesanggupan masing-masing.

c. Resource Based Learning lebih fleksibel dalam penggunaan ruang dan waktu.

d. Resource Based Learning berusaha meningkatkan motivasi belajar dengan menyajikan berbagai kemungkinan tentang metode kerja, bahan pelajaran, dan media komunikasi.

e. Resource Based Learning berusaha untuk memberi pengetahuan kepada peserta didik tentang keaneka ragaman sumber informasi yang dapat digunakan dan dimanfaatkan untuk belajar.

f. Resource Based Learning menumbuhkan kreatifitas dan mendorong peserta didik untuk lebih aktif dalam proses pembelajaran.

g. Resource Based Learning tidak meniadakan peran tenaga pendidik, bahkan terlibat dalam setiap langkah proses belajar, dalam hal ini tujuan pembelajaran serta kegiatan-kegiatan yang akan dilakukan oleh peserta didik banyak dipengaruhi oleh tenaga pendidik juga.

h. Cara belajar Resource Based Learning menggunakan cara belajar yang bermacam-macam meliputi pengajaran langsung oleh tenaga pendidik, penggunaan media belajar audiovisual, latihan- latihan memecahkan soal, pencarian bahan atau materi pembelajaran dari berbagai sumber belajar, kegiatan penelitian dan latihan-latihan formal. Adapun metode dan strategi belajar yang akan digunakan dalam proses pembelajaran tetap harus bertalian dengan tujuan pembelajaran yang akan dicapai.

\section{Tujuan Pendekatan Resource Based Learning}

Pendekatan Resource Based Learning akan merangsang kreativitas peserta didik sesuai dengan kemampuan dan kecepatan belajarnya masing-masing karena mereka selalu terhubung langsung dengan sumber belajar yang setiap pembelajaran sehingga hal ini akaan menumbuhkan motivasi daan keaktifaan peserta didik dan memberikan kesempatan untuk mengembangkan diri khususnya dalam berkomunikasi untuk mendapatkan informasi atau pengetahuan dengan menggunakaan alat, nara sumber ataupun tempat.

Menurut Suryosubroto, tujuan pendekatan Resource Based Learning adalah sebagai berikut:

1. Membantu guru memberikan informasi sebanyak-banyaknya kepada peserta didk.

2. Guru dapat mengetahui perbedaan individu baik dalam hal gaya belajar, kemampuan, kebutuhan, minat, dan pengetahuan siswa. Dengan demikian, siswa dapat belajar sesuai dengan kecepatannya masing-masing. Sumber belajar dapat dipilih sesuai dengan kebutuhan masing-masing siswa. 
3. Mendorong pengembangan kemampuan memecahkan masalah, mengambil keputusan, dan keterampilan mengevaluasi. Jadi, siswa menjadi kreatif dan memiliki ide-ide orisinil

4. Mendorong siswa untuk bertanggung jawab terhadap belajarnya sendiri. Dapat melatih siswa mandiri dalam belajar sehingga pembelajaran dapat menjadi lebih bermakna, lebih tertanam dalam dirinya karena ia sendiri secara pribadi yang menemukan dan membangun pemahaman.

5. Menyediakan peluang kepada siswa untuk menjadi pengguna teknologi informasi dan komunikasi yang efektif. Dengan demikian dapat membangun masyarakat berbasis pengetahuan (knowledge based society). Siswa akan mampu bagaimana menemukan, dan memilih informasi yang tepat, menggunakan informasi tersebut, mengolah dan menciptakan pengetahuan baru berdasarkan informasi tersebut serta menyebarluaskan atau menyajikan kembali informasi tersebut kepada orang lain.

6. Siswa akan belajar bagaimana belajar. Sekali ia melihat informasi, ia akan mengembangkan sikap positif dan keterampilan yang sangat berguna bagi dirinya dalam era informasi yang sedang dan akan dihadapinya nanti. Jadi, pada akhirnya Resource Based Learning dapat membekali keterampilan berpikir kreatif siswa.

\section{Langkah - Langkah Pendekatan Resource Based Learning}

Belajar dengan menggunakan pendekatan Resource Based Learning merupakan kegiatan belajar yang menekankan atau memusatkan kegiatan belajr tersebut pada peserta didik dan bukan pada pendidiknya, yang mana dalam hal ini peserta didik dituntut untuk dapat mempelajari sendiri bahan atau materi pembelajaran sehingga mereka akan mengalami perubahan dari segi strategi belajar, yang awalnya dari strategi belajar pasif-reseptif diharuskan menjadi strategi belajar aktif-partisipatif yang memberikan kebebasan untuk belajar sesuai dengan kemampuan dan kecepatan masing-masing peserta didik dalam menyelesaikan bahan/materi pembelajaran dengan memanfaatkan berbagai macam aneka sumber belajar.

Sumber yang sejak lama digunakan dalam proses belajar mengajar dalah buku dan hingga sekarang buku masih memegang peranan yang penting. Oleh sebab itu, ahli perpustakaan mendapat peranan yang penting dalam Resource Based Learning. Kerja sama antara pendidik dan ahli perpustakaan harus mendapat pendidikan khusus untuk menjalaankan peranannya. Pendidik dan ahli perpustakaan harus saling mengenal keahlian dan kemampuan masing-masing. Di samping itu, diperlukan pula "media specialist" , yakni ahli dalam bidang media, karena sumber belajar tidak hanya terbatas pada buku-buku saja. ${ }^{5}$

Namun demikian, pendidik harus memposisikan dirinya sebagai salah satu sumber belajar dan tetap terlibat dalam setiap pembelajaran, mulai merencanakan, menentukan daan mengumpulkan sumber informasi, menjalin kerja sama dengan beberapa pihak yang dapat menyediakan aneka sumber belajar, memberi bantuan bila

${ }^{5}$ B.Suryosubroto, Proses Belajar Mengajar di Sekolah (Cet. II; Jakarta: PT. Rineka Cipta, 2009 ), h. 217 
dibutuhkan oleh peserta didik, serta senantiasa memberikan motivasi agar peserta didik lebih aktif lagi dalam proses pembelajaran tersebut ${ }^{6}$

Menurut S. Nasution, , cara belajar Resource Based Learning perlu memperhatikan hal- hal berikut, yaitu?

1. Pengetahuan yang ada

Ini mengenai pengetahuan guru tentang latar belakaang murid dan pengetahuan murid tentaang baahan pelajaaran.

2. Tujuan Pelajaran

Guru harus merumuskan dengan jelas tujuan apa yang ingin dicaapai dengan pelajaran itu.tujuan ini tidak hanya mengenai bahan yang harus dikuasai, akan tetapi juga keterampilan dan tujuan emosional dan sosial.

3. Memilih Metodologi

Metode pengajaran banyak ditentukan oleh tujuan. Biasanya metode itu mengandung unsur-unsur sebagai berikut:

a. Uraian tentang apa yang akan dipelajari;

b. Diskusi dan pertukaran pikiran;

c. Kegiatan-kegiatan yang menggunakan berbagai alat instruksional, laboratorium, dan lain-lain;

d. Kegiatan-kegiatan dalam lingkungan sekitar sekolah seperti kunjungan, kerja lapangan, eksplorasi, penelitian;

e. Kegiatan - kegiaataan dengan menggunakan berbagai sumber belajar seperti buku perpustakaan, alat audio visual dan lain-lain;

f. Kegiataan kreatif seperti drama, seni rupa, musik, pekerjaan tangan.

4. Koleksi dan Penyediaan bahan

Harus diketahui bahan dan alat yang dimiliki oleh sekolah dan bahkan sumber-sumber lain di luar sekolah pun daapat dimanfaatkan bila diperlukan.

5. Penyediaan tempat

Segala kegiatan harus dilakukan dalam ruangan tertentu seperti ruang perpustakaan dan laboratorium.

Dalam pengajaran bahasa Arab metode yang digunakan mengalami perkembangan terus-menerus seiring dengan perkembangan yang terjadi pada disiplin ilmu bahasa (linguistik), ilmu pendidikan (pedagogi), dan ilmu jiwa (psikologi). Hasil- hasil penelitian dalam bidang pengajaran bahasa itu sendiri juga

${ }^{6}$ Menurut Ibn Jama'ah bahwa kegiatan belajar tidak hanya digantungkan sepenuhnya pada pendidik selaku orang yang memberikan informasi dan ilmu pengetahuan, melainkan juga pada anak didik. Bagi Ibnu Jama'ah, peserta didik dapat diposisikan sebagai subyek pendidikan. Untuk itu perlu diciptaakaan peluang-peluang yang memungkinkan daapaat mengembangkan daaya kreasi daan daaya intelek peserta didik oleh peserta didik itu sendiri, di samping peranan yang dilakukaan oleh orang lain. Konsep ini selanjutnya membawa kepada apa yang dikenal sebagai pemberdayaan peserta didik. Pembahasan lebih lanjut tentang konsep pendidikan dapat dilihat dalam Abuddin Nata, Pemikiran Para Tokoh Pendidikan Islam; Seri Kajian Filsafat Pendidikan Islam (Cet. II; Jakarta: PT RajaGrafindo Persada, 2001 ), h.

${ }^{7}$ S.Nasution, Berbagai Pendekatan dalam Proses Belajar dan Mengajar, h.30-31. 
memberikan kontribusi kepada lahirnya pendekatan dan metode baru dalam pengajaran bahasa. $^{8}$

Pengajaran bahasa Arab adalah suatu proses pendidikan yang diarahkan untuk mendorong, membimbing, mengembangkan kemampuan bahasa Arab baik secara aktif maupun pasif serta menumbuhkan sikap positif. Adapun yang dimaksud berbahasa Arab aktif yaitu kemampuan berkomunikasi dengan baik dan benar secara lisan, yaitu dalam berkomunikasi atau berbicara dengan orang lain maupun secara tertukis seperti membuat karangan. Sedangkan kemampuan berbahasa pasif yaitu kemampuan untuk memahami pembicaraan orang lain dan kemampuan untuk memahami isi bacaan.

Sehubungan dengan realitas yang terjadi, pendekatan Resource Based Learning diharapkan bisa memberikan solusi dalam proses pembelajaran bahasa Arab karena peserta didik tidak lagi dipandang sebagai objek pembelajaran melainkan dipandang sebagai subjek pelajaran yang diajak berfikir secara aktif seperti bertanya mengemukakan gagasan, membangun konsep dan berpartisipasi selama kegiatan pembelajaran berlangsung, mampu belajar secara individu maupun berkelompok. Pendidik dan peserta didik merupakan peserta pembelajaran bahasa yang aktif yang berbagi tanggung jawab terhadap pembelajaran bahasa peserta didik. Pendidik dan peserta diddik bekerja sama dalam mengidentifikasi bagaimana peserta didik mengharapkan penggunaan bahasa, pendidik memberi contoh penggunaan bahasa yang baik, betul dan sesuai, sementara peserta didik menggunakan model bahasa itu dalam kegiatan-kegiatan praktis yang menstimulasi situasi komunikasi yang sebenarnya yang pada akhirnya akan menghasilkan lingkungan kelas yang dinamis sehingga kegiatan belajar mengajar menjadi bermanfaat dan menyenangkan.

Dalam pembelajaran bahasa Arab, strategi belajar dengan menggunakan pendekatan Resource Based Learning dapat diaplikasikan untuk berbagai keterampilan berbahasa (maharat al-lughah), di antaranya yaitu keterampilan menyimak ( maharah al-istima / listening skill) dan keterampilan berbicara (maharah al -kalam / speaking skill); peserta didik dapat menggunakan rekaman audio / kaset, video interaktif, televisi, wawancara dengan ahli bahasa,laboratorium dan lain-lain. Keterampilan membaca (maharah al-qiraah / reading skill ); peserta didik dapat langsung diajak ke dalam sumber belajar, peserta didik dapat memanfaatkan buku, surat kabar, majalah, artikel, jurnal, kamus, komputer, perpustakaan dan lain-lain untuk dapat menemukan dan membaca sendiri sumber belajar secara bersama-sama. Keterampilan menulis (maharah al-kitabah / writing skill); peserta didik dapat memanfaatkan lingkungan sekitar, internet, komputer, surat kabar, majalah, dan lainlaiin. Apa saja yang ada di sekitar tempat pembelajaran, semuanya dapt digunakan untuk membantu menyampaikan materi pembelajaran, termasuk bahasa dan mimik muka pendidik yang sedang mengajar adalah bagian dari media pembelajaran.

Sumber- sumber belajar yang bisa mendukung untuk pembelajaran bahasa Arab, antara lain:

1. Manusia, yaitu orang yang menyampaikan pesan pengajaran secara langsung seperti pendidik ataupun pembimbing ${ }^{9}$

${ }^{8}$ Ahmad Fuad Efendi, Metodologi Pengajaran Bahasa Arab ( Malang, Misykat, 2004 ), h. 1.

${ }^{9}$ Media manusia bisa mengarahkan serta mempengaruhi proses pembelajaran melalui eksplorasi terbimbing dengan menganalisis setiap saat apa yang terjadi pada lingkungan belajar, lebih 
2. Bahan / materi, yaitu sesuatu yang mengandung pesan pelajaran, seperti buku-buku daras, majalah, koran, jurnal ataupun film-film dokumenter.

3. Lingkungan, yaitu ruang dan tempat ketika sumber-sumber dapat berinteraksi dengan peserta didik seperti kelas, laboratorium dan perpustakaan $^{10}$

4. Alat dan peralatan, yaitu sumber belajar produktif yang berfungsi untuk memainkan sumber-sumber lain, seperti Televisi, Radio, Tape Recorder, VCD.

5. Aktifitas, yaitu sumber belajar yang mengkombinasikan dengan sumber lain memudahkan pesert didik dalam belajar seperti karyawisata ${ }^{11}$, kerja lapangan, eksplorasi dan simulasi.

Penggunaan media dalam pengajaran bahasa bertitik tolak dari teori yang mengatakan bahwa totalitas persentase banyaknya ilmu pengetahuan, ketrampilan, dan sikap yang dimiliki oleh seseorang terbanyak dan tertinngi melalui indra lihat dan pengalaman langsung melakukan sendiri, sedangkan selebihnya melalui indra dengar dan indra lainnya.

Media pembelajaran itu dapat dibagi menjadi tiga ${ }^{13}$, yaitu:

1. Media Audio ( al-wasa'il al-sam'iyyah)

Media audio adalah segala sesuatu yang dapat dimanfaatkan untuk memudahkan pembelajaran bahasa yang dapat ditangkap dan dicerna melalui indra pendengaran. Misalnya bahasa, tape recorder, radio transistor, televisi, laboratorium bahasa, dan sebagainya.

2. Media Visual ( al-wasa'il al-bashariyyah)

Media visual adalah segala sesuatu yaang dapat dimanfaatkaan untuk memudahkan proses pembelajaraan bahasa yang dapaat ditangkap dan dicerna melalui indra penglihatan. Misalnya benda asli, benda tiruan, gambar, papan tulis, papan pengumuman, papan plannel, papan kantong, stick figures (gambar yang dibuat langsung oleh guru) strip story ( kepingan kertas), flash card ( kartu

lanjut tentang media manusia dapat dilihat dalam Azhar Arsyad, Media Pembelajaran, ( Cet.V; Jakarta; PT RajaGrafindo Persada; 2004 ), h. 82-87

${ }^{10}$ Pemanfaatan perpustakaan sebagai sumber belajar secara efektif memerlukan keterampilan, yaitu: Keterampilan mengumpulkan informasi, keterampilan mengambil intisari dan mengorganisasikan informasi, keterampilan menganalisis, menginterpretasikan, dan mengevaluasi informasi, serta keterampilan menggunakan informasi, lebih lanjut dapat dilihat dalam Azhar Arsyad, Media Pembelajaran, h. 103 - 104

${ }^{11}$ Lebih lanjut tentang metode karya wisata dapat dilihat dalam Tayar Yusuf dan Syaiful Anwar, Metodologi Pengajaran Agama dan Bahasa Arab ( Cet. II; Jakarta; PT RajaGrafindo Persada, 1997 ), h. 84-87.

${ }^{12}$ Acep Hermawan, Metodologi Pembelajaran bahasa Arab ( Cet IV; Bandung: Remaja Rosdakarya, 2014), h. 225.

${ }^{13}$ Acep Hermawan, Metodologi Pembelajaran bahasa Arab, h. 227. Bandingkan juga dengan Azhar Arsyad, Bahasa Arab dan Metode Pengajarannya;Beberapa Pokok Pikiran ( Cet. III; Yogyakarta: Pustaka Pelajar, 2010 ), h. 76-79 dan S. Nasution, Teknologi Pendidikan ( Cet III; Jakarta: Bumi Aksara, 2005 ) h. 101 
pengingat), buku teks, buletin, slides proyektor, OHP, komputer, LCD Proyektor, dan sebagainya. Keberhasilan media berbasis visual ini sangat ditentukan oleh efektifitas dan kualitas bahan - bahan visual dengan cara mengatur dan mengorganisasikan gagasan - gagasan yang timbul dan merencanakannya dengan seksama.

3. Media audio-visual (al-wasa'il al-sam'iyyah al-bashariyyah )

Media audio-visual adalah segala sesuatu yang dapat dimanfaaatkan untuk memudahkan pembelajaran bahasa yang dapat ditangkap dan dicerna melalui indra pendengaran dan penglihatan. Misalnya Televisi, video $\mathrm{CD}$, film layar lebar, laboratorium bahasa multimedia, LCD Proyektor, internet dan sebagainya. Hal penting yang perlu dilakukan dalam media audio-visual adalah penulisan naskah dan Storyboard yang membutuhkan persiapan yang banyak, rancangan dan penelitian.

Adapun media teknologi informasi yang saat ini bisa digunakan sebagai sumber belajar dalam pembelajaran bahasa Arab, yaitu:

\section{Internet}

Penggunaan internet untuk keperluan pendidikan semakin meluas, terutama di negara-negara maju. Melalui internet, memungkinkan para tenaga pendidik untuk menggali informasi dan ilmu pengetahuan yang menjadi bahan materi ajarnya.sehingga akan selalu siap mengajarkan ilmu pengetahuan yang mutakhir kepada peserta didik.. Hal ini tentu saja menuntut kemampuan tenaga pendidik itu sendiri untuk selalu giat mengakses website dalam bidang yang menjadi keahliannya. Melalui internet, peserta didik dapat mengadakan kontak langsung dengan penutur asli, berpartisipasi dalam suatu forum diskusi , dan sebagainya. Interaksi antara pendidik dan peserta didik, misalnya penugasan dan pengerjaan tugas pun dapat dilakukan melalui internet. Situs- situs yang berhubungan dengan bahasa Arab banyak disajikan di internet dan sangat membantu penguasaan kemahiran berbahasa Arab yang menyajikan berbagai data dan informasi mengenai dunia arab serta kajian bahasa Arab dan Islam.

\section{CD Interaktif}

Adanya Compact disk (CD) interaktif juga merupakan media pengajaran yang cukup efektif digunakan dala pembelajaran bahasa, perkembangan teknologi yang semakin pesat dan modern makin mempermudah pendidik untuk memanfaatkan berbagai macam media yang ada. Saat ini telah banyak program-program pengajaran bahasa arab yang dikemas dalam bentuk CD yang dapat digunakan pada perangkat komputer, VCD, DVD maupun perangkat audio visual lainnya.

\section{Satelit / Parabola.}

Satelit juga memberi kemudahan bagi para pendidik dalam mengajarkan bahasa Arab dan pengenalan tentang budaya Arab, Dengan Televisi yang menggunakan parabola, kita dapat menikmati siaran TV berbahasa Arab dari berbagai negara secara langsung dan ini sangatlah bermanfaat untuk meningkatkan keterampilan menyimak dalam bahasa Arab.Siaran tersbut dapat direkam sehingga memungkinkan untuk dapat diputar berulang kali sebagai alat peraga.

4. Arabic E-Learning 
Istilah Arabic E-Learning merupakan suatu jenis belajar mengajar yang memungkinkan tersampaikannya materi atau bahan ajar kepada peserta didik dengan menggunakan media internet, Intranet atau media jaringan komputer lain

Dengan mengunakan atau memanfaatkan media teknologi yang ada pada saat ini, maka peserta didik akan semakin mudah untuk belajar dan menguasai materimateri yang ada di manapun dan kapan pun mereka inginkan.

Dalam hal ini peserta didik mengalami secara langsung dengan memanfaatkan banyak indera melalui pengamatan, percobaan, penyelidikan, ataupun wawancara sehingga peserta didik akan belajar banyak melalui berbuat. Selain itu, refleksi merupakan hal penting lainnya agar pembelajaran lebih bermakna. Pembelajaran yang bermakna adalah pembelajaran yang memungkinkan adanya refleksi dari peserta didik ketika mempelajari sesuatu, dalam hal ini refleksi yang dimaksud adalah memikirkan kembali apa yang sudah diperbuat atau dipelajarinya. Dengan refleksi peserta didik bisa menilai efektif tidaknya pembelajaran, karena bisa saja setelah direfleksi pelajarannya menyenangkan namun ternyata tingkat penguasaan terhadap substansi atau materi masih rendah atau belum tercapai sesuai yang diharapkan.

\section{Kesimpulan}

Keberhasilan pendekatan Resource Based Learning sangat dipengaruhi oleh keaktifan peserta didik dalam setiap proses pembelajaran yang menggunakan beranekaragam sumber belajar untuk mendapatkan informasi dan pengetahuan terhadap materi pembelajaran sehingga dapat meningkatkan penguasaan dan pemahamaan terhadap materi ajar secara cepat . Dalam hal ini pendidik sebagai salah satu sumber belajar, juga memainkan peran sebagai fasilitator, dinamisator dan motivator dalam pembelajaran.

Tidak semua metode dapat diterapkan dalam pembelajaran bahasa Arab, hal ini disebabkan oleh berbagai faktor seperti kondisi peserta didik, tempat dan waktu, banyak sekali ditemukan perbedaan dan persamaan metode antara satu lembaga dengan lembaga lainnya.

Strategi belajar bahasa Arab dengan menggunakan pendekatan Resource Based Learning dapat diaplikasikan untuk berbagai keterampilan berbahasa ( maharat allughah), di antaranya yaitu keterampilan menyimak ( maharah al-istima / listening skill), keterampilan berbicara (maharah al -kalam / speaking skill), keterampilan menulis ( maharah al-kitabah / writing skill ) dan keterampilan membaca ( maharah al-qira'ah / reading skill ). 


\section{DAFTAR PUSTAKA}

Arsyad, Azhar.Bahasa Arab dan Metode Pengajarannya;Beberapa Pokok Pikiran. Cet. III; Yogyakarta: Pustaka Pelajar, 2010.

Arsyad, Azhar. Media Pembelajaran, Cet.V; Jakarta; PT RajaGrafindo Persada; 2004.

Efendi , Ahmad Fuad.Metodologi Pengajaran Bahasa A rab. Malang, Misykat, 2004.

Hermawan ,Acep.Metodologi Pembelajaran bahasa Arab. Cet IV; Bandung: Remaja Rosdakarya, 2014.

Nata, Abuddin. Pemikiran Para Tokoh Pendidikan Islam; Seri Kajian Filsafat Pendidikan Islam.Cet. II; Jakarta: PT RajaGrafindo Persada, 2001.

S.Nasution, Berbagai Pendekatan dalam Proses Belajar dan Mengajar.Jakarta: Budi Aksara, 2008.

S. Nasution, Teknologi Pendidikan, Jakarta: Bumi Aksara, 2005

Sagala,Syaiful. Konsep dan Makna Pembelajaran. Cet. VI; Bandung: Alfabeta, 2008.

Suryosubroto. B, Proses Belajar Mengajar di Sekolah. Jakarta: PT. Rineka Cipta, 1997.

Yusuf, Tayar dan Syaiful Anwar, Metodologi Pengajaran Agama dan Bahasa A rab.Cet. II; Jakarta; PT RajaGrafindo Persada, 1997.

Zulhannan, Teknik Pembelajaran Bahasa Arab Interaktif. Cet. II; Jakarta; PT RajaGrafindo Persada, 2015. 